\title{
3. Crossing the great divide: Australia and eastern Indonesia
}

\author{
Anthony Reid
}

\section{Introduction}

The enterprise of understanding 'Macassan history and heritage' is one of valorising the many crossings of the gulf between northern Australia and eastern Indonesia. To do justice to those crossings, however, we must first of all clarify the immensity of the gulf itself, which I will call 'the Great Divide'. Viewed in the long term, it is a divide more fundamental than that between any other two neighbours in the world, and the crossings of it were no mean feat. Once humans extended the use of efficient sailing craft into the waters north of Australia some thousands of years ago, that divide would have been expected to be bridged, but it was not. I will end my story by seeking to explain the depth of the mutual incomprehension as late as the 1930s, on the very eve of the violent collision of the two neighbouring peoples in the crucible of war in the 1940s.

\section{Sunda and Sahul}

Looked at over the long term, the Arafura Sea has formed the world's greatest divide throughout human history. As we know, some hundreds of millions of years ago Australia, or more accurately the broader Sahul plate it formed together with the island of New Guinea, was united with the other southern continents in what geologists call Gondwana. Africa, South America and the Indian subcontinent in turn tore themselves off from Gondwana and began their journey northward, a journey that would ultimately join them with the great northern landmass of Laurasia, or today's Eurasia and North America. Sahul was the last plate to be torn from Antarctica, only 50 million years ago, to begin its journey northward towards what we now know as Southeast Asia. But instead of joining up with the northern plate, as South America did at Panama and Africa at Suez, Sahul created a great rumpling in the space between Sahul and Sunda, the deep troughs that form Wallacea, with its Wallace and Weber lines, and with Sulawesi in the middle, itself composed of two disparate pieces of plate thrust awkwardly together. These rifts between Sunda and Sahul remained so 
profound that even the most extreme ice ages of the past million years could not lower sea levels enough to make it crossable by the humans of the major northern continent; whereas at various times it was possible to walk across the Bering Strait to America. Hence the extreme difference of Australia's fauna and flora from those of the Eurasian landmass, and the virtual impossibility for primates and our human ancestors to reach the world's only truly isolated liveable continent.

But somehow Homo sapiens did make this crossing, arriving at a time now thought (since 2011's genome analysis of a lock of hair) to be as much as 70 000 years ago, before northern Asia or Europe were populated at all. They thereby became the only fully isolated human population for the next 60000 years or so before boats became part of human equipment. How they could have done this remains a great conundrum, as is the issue of what happened to their relatives who stayed behind in the closer parts of Sunda, where of course they had to cope with intrusions from the north, or much earlier from the west, if we believe the Sundaland hypothesis of Steven Oppenheimer (1999), of people who had developed tools and agriculture that they lacked. I think this issue is the most fundamental part of the agenda of this collection, and indeed of much Australian scholarship. It is the question that drove John Mulvaney to begin archaeological work in South Sulawesi in 1969, and for later Australian prehistorians to extend their work to the eastern Indonesian islands closest to Sahul, and to develop the most fruitful (if often difficult) of the scholarly cooperations between Australia and (eastern) Indonesia. The most spectacular result so far was the unexpected discovery in 2003 of Homo floresiensis (Flores man, nicknamed 'the hobbit' for his diminutive stature), who also somehow crossed the Wallace Line at a remote time, though not the much wider gulf to Sahul. The cooperation between Australian prehistorians (with some advanced technology and funding), Indonesian scholars and the local knowledge of the people of Nusa Tenggara Timur was essential to this progress, and needs to be extended.

Adding to the complexity of this human history across the Great Divide is the unusual dynamism of this region geologically. Because it forms a complicated and highly active part of the Ring of Fire, the landforms may have been dramatically altered by eruptions, earthquakes and tsunamis as well as the rise and fall of sea levels. We now know that massive eruptions such as those of Long Island (Papua New Guinea) in \pm 1660 (Blong 1982), Tambora (Sumbawa) in 1815 and Krakatau (between Sumatra and Java) in 1883 cast a massive ash deposit over hundreds of kilometres to their west, and caused darkness and climatic cooling around the planet, and the failure of agriculture within their own region for a year or two. 
But since most of our knowledge of the 70000 years of possible human contact between Sahul and Sunda is crammed into the past 500 years, let me focus the remainder of the chapter on that. What follows is a review of some of the contacts we do know about across this divide in relatively recent times.

\section{Tracing shadows before the nineteenth century}

Once the Austronesians arrived in the southern islands some 5000 years ago with their efficient outrigger sailing vessels, which could sail as far as Easter Island and Madagascar, the depth of the sea was no longer an adequate reason for the sporadic nature of the contact. From a maritime trading perspective, one might have expected the northwest coast of Australia to become part of a kind of 'Arafura zone' centred on one of the busy commercial hubs of those seas, just as James Warren (1981) identified a 'Sulu zone' of interaction in the Sulu Sea, around the small-island trading and raiding centre of Sulu, which in turn depended for its wealth on the visits of Chinese traders. Tidore provided such a hub for the western regions of Papua, ensuring that by the sixteenth century coastal west Papua, manifestly part of the Sahul geological plate, was also incorporated into the great Eurasian trading world.

That world did not peter out slowly in the southeast, but extended vigorously as far as the spice islands of Maluku. The cloves of Ternate and Tidore and the nutmeg of the Banda Archipelago were both items of Eurasian trade throughout the Common Era, having been found both in ancient Rome and in Han China. They became indispensable to the European pharmacopeia in the late Middle Ages, and the lust to obtain them without dependence on Muslim trading routes was what had united the world in Europe's age of discovery. In the sixteenth century Banda became another small-island trading hub, relatively safe from predatory rulers and dominated by a cosmopolitan group of traders from around the archipelago. Its conquest and depopulation by the Dutch in 1623 required free merchants to find other centres - in the first instance in other small islands to the east of Ceram, particularly Goram (Knaap 1987, pp. 53-8). By the early nineteenth century, Dobo in the Aru Islands (see below) had become the smallisland free port closest to Australia, and a classic exemplar of the genre, though there were others, like Bawean in the Java Sea and Bonerate further east.

In the sixteenth century the rival sultanates of Ternate and Tidore, each based on a tiny clove-producing volcanic island within sight of the other, became little Sulus seeking to coordinate multi-ethnic fleets that could raid or trade for slaves and sea produce as far as Aru, Kei, Tanimbar and Papua. Their languages were Papuan rather than Austronesian, and their myths confirmed ancient connections of trade, warfare and ritual to Papua in the east. Andaya (1993, 
pp. 49-55, 100-12) includes 'the king of the Papuas' as one of the complementary four pillars of his 'World of Maluku' delineated by origin myths. Dutch sources in the seventeenth century show Tidore as the most active claimant to primacy throughout the islands to its east, with major centres of its influence in the Papuan offshore islands of Misool and Raja Ampat, and contacts with the Onin Peninsula on the mainland. Further south, the sandalwood-trading network linked Timor and its nearby islands into the great Eurasian trading world. Rote, the island call for many latter-day Indonesian voyages to Australia, was in trade and treaty relations with the Dutch from 1662 and largely Christianised in the following century.

Why was the Australian coast so much less visited? Of course the distance across the Timor Sea (though not the Torres Strait for coast-huggers) was several times the distance of any sector on the route to western Papua. But the more important point seems to have been that visitors found almost nothing of value on the Australian northwest coast, and moved quickly away. As Dampier (1981, p. 149) complained in 1699, this coast 'was not very inviting, being but barren towards the sea, and affording me neither fresh water, nor any great store of other refreshments, nor so much as a fit place for careening'. Accidental Austronesian navigators who visited this inhospitable coast would have been little different from the seventeenth-century Dutch in spending as little time as possible on it.

\section{Nineteenth-century contacts}

I said almost nothing of value, but that almost is the entry to what contact there was. Australia offered no trade goods on the scale of cloves, nutmeg or sandalwood, and no staple cereals such as rice. For the long-distance traders to know about the potential trade wealth of a place, that wealth had already to be exploited by the locals, as was the case with the products of the Indonesian islands. The native Australians were not miners who valued gold or iron, to present a point of entry to the gold or iron ore that would have attracted Chinese, Indonesian or European traders to the northwest; nor were they agriculturalists who could provide recognisable food sources (except seafood). But they were coastal scavengers of apparently a very high order. The question even more enticing than the trepang trail is that of pearls and pearl shell. Whereas the historical demand for trepang has been well documented as beginning only in the eighteenth century (Knaap and Sutherland 2004), the pearls of tropical Asia were desired trade commodities for 2000 years, often mentioned in Chinese sources as among the trade and tribute items from Southeast Asian maritime centres. If female Aboriginal 'naked divers' of the Kimberley area were as exceptionally good as some of the European pioneers reported in the 1850s, it seems unlikely that they only began diving at European behest. If there is 
a longer history of contact across the Great Divide, it should be sought in the coastal marine resources for which the Arafura region was well known - in the first place pearls and pearl shell, but also tortoise shell, valued in China for many centuries.

Dobo, a tiny island in the Aru archipelago, appears to have flourished as a typical small-island entrepot free of political interference from any state, Indonesian or Dutch, and useful as a collecting point for sea produce. The Makassar kingdom was in contact with Aru as early as 1624, and a Dutch report then advised that there were already seven mosques in the archipelago because of the importance of this commercial and political link (Coolhaas, vol. I, p. 166). But the pearl industry may not have developed there until the third quarter of the nineteenth century. John Crawfurd insisted in his 1820 History of the Indian Archipelago that pearls 'are found no where but in the Suluk [Sulu] Islands' in Indonesian waters, and that it was from there that they were exported in vast quantities to China. He reckoned 25000 Spanish dollars worth of pearls, and 70000 of pearl shell, were sold in Sulu every year for the China market (Crawfurd 1820, vol. III, p. 415). But in his later 1856 Descriptive Dictionary, Crawfurd described the whole eastern coast of Aru as being 'rich in the shell-tortoise, two kinds of mother-of-pearl shells, and in pearl oysters, with the tripang'. Every year in the season there came ' 100 small square-rigged vessels and large native craft with Chinese junks', bringing rice, cloth and provisions in exchange for the sea produce and exotic birds (Crawfurd 1971, p. 24). What had happened in between was a movement south and east of Sama Bajau divers and scavengers from Sulu waters to Maluku and eventually Aru, driven in part by the greater opportunities of virgin fields, but perhaps also by the great increase of Iranun raiding in the latter part of the eighteenth century, which made the whole Sulu zone unsafe (Warren 1981, pp. 160-5; Andaya 1993, pp. 230-3).

Best known, of course, was the evocative description of Dobo in 1857 by the creator of the Wallace Line, naturalist Alfred Russell Wallace:

Every house is a store, where the natives barter their produce for what they are most in need of. Knives, choppers, swords, guns, tobacco, gambier, plates, basins, handkerchiefs, sarongs, calicoes, and arrack, are the principal articles wanted by the natives; but some of the stores contain also tea, coffee, sugar, wine, biscuits, \&c., for the supply of the traders; and others are full of fancy goods, china ornaments, lookingglasses, razors, umbrellas, pipes, and purses, which take the fancy of the wealthier natives. Every fine day mats are spread before the doors and the trepang is put out to dry, as well as sugar, salt, biscuit, tea, cloths, and other things that get injured by an excessively moist atmosphere. In the morning and evening, spruce Chinamen stroll about or chat at each other's doors, in blue trousers, white jacket, and a queue into which 
red silk is plaited till it reaches almost to their heels. An old Bugis hadji regularly takes an evening stroll in all the dignity of flowing green silk robe and gay turban, followed by two small boys carrying his sirih and betel boxes...

I daresay there are now near five hundred people in Dobbo of various races, all met in this remote corner of the East, as they express it, 'to look for their fortune'; to get money any way they can. They are most of them people who have the very worst reputation for honesty as well as every other form of morality,-Chinese, Bugis, Ceramese, and halfcaste Javanese, with a sprinkling of half-wild Papuans from Timor, Babber, and other islands, yet all goes on as yet very quietly. This motley, ignorant, bloodthirsty, thievish population live here without the shadow of a government, with no police, no courts, and no lawyers; yet they do not cut each other's throats, do not plunder each other day and night, do not fall into the anarchy such a state of things might be supposed to lead to. It is very extraordinary...Think of the thousands of lawyers and barristers whose whole lives are spent in telling us what the hundred Acts of Parliament mean, and one would be led to infer that if Dobbo has too little law, England has too much.

Here we may behold in its simplest form the genius of Commerce at the work of Civilization. Trade is the magic that keeps all at peace, and unites these discordant elements into a well-behaved community. All are traders, and know that peace and order are essential to successful trade, and thus a public opinion is created which puts down all lawlessness. (Wallace 1869)

By Wallace's time the trading interest in pearls and pearl shell had spread to the northwest Australian coast, though the existing literature on it appears all to be from the British/Australian side. At first Aboriginal divers were used, but in the 1870s Indonesians began to be recruited, providing the most important economic connection across the Great Divide. The first eight Indonesians were brought from Batavia to Shark Bay in the northwest in 1871, but immediately thereafter 44 'Malays' were brought in from Makassar by Francis Cadell. This rose quickly to almost 1000 in 1875, the year when Cadell's harsh treatment of his work force caused a scandal, the intervention of the Netherlands Indies Government, and the virtual collapse of this site for the industry. The centre of activity shifted to the Broome area, where diving suits were introduced and in consequence the preferred divers became those more familiar with the technology. Aboriginal divers disappeared, and Filipinos and Japanese became more numerous. Two of the Filipino (Visayan) divers, Francisco del Castillo and Candido Iban, were responsible for probably Australia's most important contribution to Southeast Asian history before 1942, by devoting much of their 
earnings in Broome, enhanced by a lottery win, to the underground Katipunan society of Bonifacio in 1895. This enabled the society to buy a printing press, on which it launched its revolutionary newspaper, Kalayaan (Freedom)-banned after the first issue. All these events are now sanctified in the historiography of the Philippine Revolution of 1896, in which for all its exploitation of Southeast Asian labour, the pearl fisheries of Broome can be said to have played their part (Zaide 1931).

Broome was by 1910 the largest pearling centre in the world, and its diving force included people from Timor, Makassar and Ambon as well as the Philippines and Japan. I believe further research into the earlier history of pearling would be rewarding, even more perhaps than in the case of trepang, to understand connections across the Arafura Sea. Better known, however, thanks to Campbell Macknight and his successors, is the trepang trade that developed in response to growing demand in China in the eighteenth century, mediated through Sulu and later Makassar. The active sea scavengers who collected it were most frequently Sama Bajau, it appears, though working closely with Bugis, Butonese and other traders with bigger ships and more access to capital. Matthew Flinders encountered them on the Australian coast, and understood that they had shifted their operations progressively further south, to the Aru Islands, Rote, Ashmore Reef and finally the northwest Australian coast towards the end of the eighteenth century. He describes the kind of accidental process that must often have happened in the past, whereby a boat was driven off course onto the coast. But whereas earlier accidental visitors could not get away soon enough, the Bajau sea scavengers found exactly what they were looking for, and came back for more (Flinders 1814, vol. II, p. 257, cited in Fox 2005).

\section{Twentieth-century separations}

The twentieth century, however, brought a distinct deepening of the Great Divide, as new concepts of exclusive sovereignty defined and enforced a national boundary along it. On the one hand, the Dutch succeeded in knitting their scattered island domain together with a network of shipping routes through their Royal Packet Line (KPM), which linked all their islands to each other but not to northern Australia. On the other hand, Australia began its history as a collective federal state with a burst of exclusive regulations forbidding or discriminating against any intrusion or recruitment from the north. The Immigration Restriction Act of 1901 put an end to the use of Indonesian labour for northern fisheries or Queensland plantations, and had many other negative effects on the normal relationships of neighbours. 
Australia and Indonesia grew steadily further apart from each other, though closer to their respective imperial capitals on the opposite side of the world. Dutch and Malay languages, media and education systems, and Netherlands Indian currency, law and exchange networks spread throughout the eastern islands, tying them into the archipelagic political economy that would give birth to Indonesia. Their English/Irish/Australian equivalents did the same for the Australian continent, ensuring that the coastal northwest would become a peripheral frontier of Australia, not of the tropical archipelago. Although in some respects the economies of Indonesia and Australia should have been complementary, imperial preference as well as simple laziness and unfamiliarity ensured that interaction of any kind became minimal. In the 1930s (and perhaps indeed into the 1960s), both Indonesians and Australians knew far more about Europe than about each other.

\section{The Pacific War: Encounter without preparation}

It was the rise of a threatening Japan that shook the whole colonial order in eastern Asia, including the back-to-back non-relationship between Australia and Indonesia. One early consequence of the rising tension had already occurred in 1934, when a trade delegation sailed from Sydney to Batavia, leading to the appointment of Australia's first trade commissioner in Batavia (Jakarta) the following year. The journalist Richard Moorehead was aboard and published a book about this 'goodwill' voyage (Moorehead 1934). The delegation also visited Makassar, and Moorehead must have been particularly struck by its exoticism, mystery (in the sense of widespread ignorance) and perhaps by the puzzlingly dynamic but hierarchic nature of South Sulawesi society. He subsequently wrote what I presume was the first Australian novel about it, an appalling boy's own adventure about a swashbuckling Australian hero who meets a mysterious but thoroughly 'white' woman among the Torajan death-statues (tau-tau). The Mists of Macassar was published only in 1946, when perhaps its relevance to the hundreds of diggers in Sulawesi was thought to compensate for its dreadful racial fantasies (Moorehead 1946).

As war approached in Europe, and particularly once Hitler occupied the Netherlands (May 1940), Indonesia and Australia were obliged to pay more attention to each other in strategic terms. By 1939, 5 per cent of Indonesia's trade was with Australia, and 14 per cent of the small numbers of Bali tourists were Australians (Reid 1995, p. 4). Nevertheless, the military connections that began at the end of 1940 came in a relative vacuum. Once Holland had fallen Australian assistance looked essential to Netherlands Indies strategists, though 
they did not want to look weak before their Indonesian subjects by admitting it publicly. It was agreed secretly that Australians would reinforce Timor, Ambon and Java as soon as war came to the Pacific. Preparations were also made secretly, and the men were on their way within a week of Pearl Harbor in December 1941, without any chance for education about where they were headed. About 1100 Australians went to Ambon, where most died in a heroic defence of the strategic port and airport against the Japanese in February 1942. Another 1400 landed in Timor, where the majority were killed or captured in February, though 400 held out in the interior with the support of the local population until they could be taken off by ship. About 3000 were sent to Java where most were taken prisoner at the Dutch surrender. Their memories, therefore, may have been more of cruel Japanese prison guards and ineffective Dutch allies than of Indonesians.

At the end of the war on 14 August 1945, what was at stake was no longer the defence of a colonial system but its restoration under radically changed conditions. The unexpectedly sudden Japanese surrender, following two horrendous nuclear bombs, found newly liberated Holland in no position to take charge. Its Netherlands Indies Government was based in Australia, and having increasing difficulty controlling its Indonesian employees, let alone the political prisoners evacuated to Australia from internal exile in Digul (Papua) and long since freed under Australian union pressure. A popular nationalist movement had been encouraged and publicised by the Japanese during their last desperate year of occupation, and it declared Indonesian independence on 17 August.

At the surrender, Australia already had 50000 men on the soil of Kalimantan (Indonesian Borneo) and East Indonesia, after its massive bombardment and invasion of the oil towns of Tarakan (May 1945) and Balikpapan (July 1945). As a member of the victorious Allied Forces with specific East Indonesian responsibilities, Australia had a potentially decisive role in the post-war order. Would Allied commitments to restore the prewar (colonial) legal order be honoured, or would the democratic values for which the war had nominally been fought be held to apply also to the Asian colonies?

Fortunately, the story best remembered both in Australia and in Indonesia is that memorably immortalised in the film Indonesia Calling, chronicling the activity of independence activists among the Indonesians in Australia, and the support for them in the Australian Communist Party, the unions and to a lesser extent the postwar Labor government. Through these means, Indonesia and Australia became sympathetically aware of each other for the first time, and a small but idealistic cohort of young Australians responded to the excitement of an embattled new nation. The story has been well told in the books of activists of the time, including Rupert Lockwood (1975) and Molly Bondan (1992), as well as academic Margaret George (1980). 


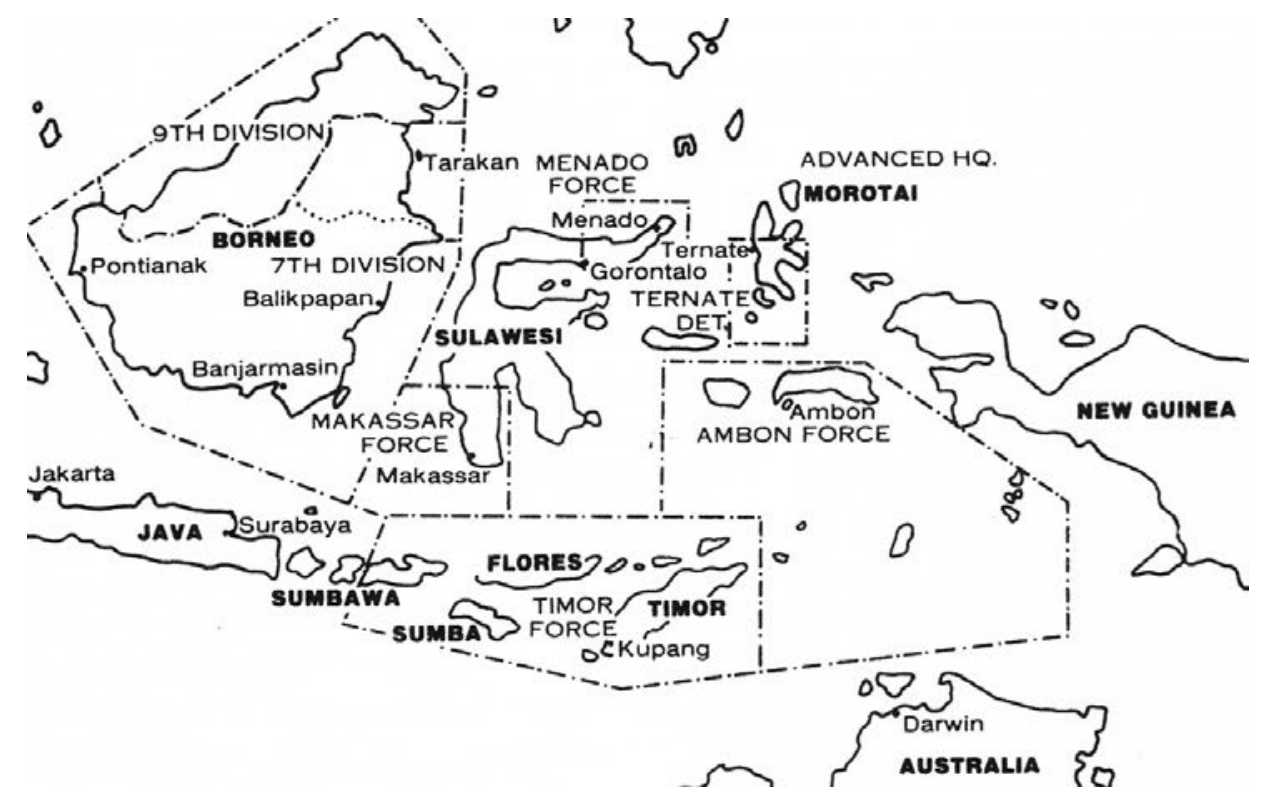

Figure 3.1 Australian military occupation of Borneo and East Indonesia, 1945-46

Source: ANU Cartography Unit

The largest-scale encounter of the two peoples was of a quite different kind, however, as tens of thousands of young Australians suddenly found themselves as occupying troops responsible for a population of east Indonesians in excess of Australia's. That occupation was woefully under-prepared. For the most part, Australian political and military leadership had accepted colonial-era assumptions that expertise in dealing with 'native populations' belonged with the colonial regimes, and that difficult postwar problems would be left to Britain and the Netherlands to sort out. There was resistance to colonial arrogance on the part of Australia's mercurial foreign minister H. V. (Doc) Evatt and some of the young intellectuals thrown into positions of influence at the end of the war, but insofar as this had practical planning results it was chiefly at the expense of the British. Alf Conlon had established a 'Directorate of Research' within the wartime government early in 1945, and this spawned a 'British Borneo Civil affairs Unit' on 30 April of that year, as planning was under way for the Australian occupation of Sarawak and Sabah. The Borneo Book for Servicemen was prepared to assist the occupying troops. It contained only four paragraphs on the Dutch East Indies, which briefly summarised the prewar colonial structure but never mentioned nationalism or the strange word 'Indonesia'. The most useful advice was contained in the words: 'The native, whether Mohammedan, Pagan or Christian, has no reason to love the white man any more than he does the Jap. If he gets a better deal from the Jap than he does from you-well, what then?' (AMF 1945, p. 23). 
This was at least an improvement on the advice contained in the only previous guidance offered, in the few hundred copies of a simple Malay vocabulary prepared in 1944 for Royal Australian Air Force (RAAF) personnel shot down in Indonesia/Malaysia. This began with four pages of racial stereotypes deriving from some old hand from colonial Malaya - namely, that the Malays were 'an easy-going and rather lazy race', but would 'in most cases show respect for, and willingly assist the white man' (cited in Reid 1990, p. 33).

Despite widespread irritation with Dutch officials on the ground, not even Conlon's group appeared to have the confidence that they could replace Dutch expertise on Indonesia. The Australian military had been accustomed to operating under General Douglas McArthur's Southwest Pacific Command. When suddenly entrusted by McArthur in August 1945 with the task of taking the Japanese surrender and restoring prewar Dutch rule in Borneo and eastern Indonesia, they received no instructions from Canberra that might have nuanced this. Their ignorance of that prewar order was in general a grave handicap, but could also be an asset in imaginative hands. There were plenty of cases where diggers were required to protect and enforce the early Dutch steps to reclaim authority, while protesting nationalists were shot by Australian troops. Whereas in Sumatra and Java the responsible British forces under Mountbatten felt obliged to remain neutral between the Dutch and the newly proclaimed Indonesian Republic, the Australians did fulfil the task assigned them of restoring Dutch authority throughout Borneo and eastern Indonesia. The main test for the Australians was South Sulawesi, where there was an active independence movement comparable with that in Java and Sumatra. After some hesitation under the initial commander, Ivan Dougherty, a new commander from October forced the local rajas to accept the Netherlands Indies Civil Administration (NICA) and arrested the Indonesian-appointed Governor of Sulawesi, Dr Ratulangie (Reid 1986, 1990).

Despite this, Australians were relatively well remembered in the region. Part of the reason is the national-level story of Australian support for the Republic, and part the obvious fact that Australians arrived well supplied with goodies after a time of terrible hardship, and made it obvious they did not want to stay but to get home as soon as possible. But there was also the extraordinary role of some individual young men who sympathised with the Indonesians either passively or actively. Most active were the handful of members of the Australian Communist Party, largely concentrated in the Army Education Unit, who managed to smuggle in pro-independence pamphlets prepared by the Indonesian committee in Melbourne, and distribute them to surprised Indonesians in the occupied cities of Kalimantan. The principal Indonesian chronicler of the independence movement in Kalimantan's largest city, Banjarmasin, noted what a powerful impact these had. 'People were overjoyed and thought that these pamphlets were 
officially authorised by Australia, since they were distributed by members of its military' (Basry 1962, p. 17). One member of this group was impressed enough by the independence movement to volunteer to serve in Makassar, where he knew the movement was strongest. This was John Cohen, Jewish and Germanborn, who became almost a disciple of the nationalist leader Ratulangie. They shared the German language (Ratulangie had his doctorate from Zurich) and passionate interests in both politics and culture. Cohen was one of the few who had the openness and the intellectual equipment to respond enthusiastically to the eastern Indonesia he encountered (Reid 1990, p. 38).

The war brought Indonesians to Australia, and Australians to Indonesia, crossing the Great Divide in their tens of thousands for the first time. Much was learned on both sides, but it was too early to break down barriers. White Australia was still enforced, and even the couples who married across the Divide could not live in Australia. Much progress has been made since, but the Great Divide remains, now more heavily policed than ever, waiting for more constructive bridges to be built.

\section{References}

Andaya, L. (1993) The World of Maluku, Honolulu: University of Hawai'i Press.

Australian Military Forces (AMF) (1945) The Borneo Book for Servicemen, Australia.

Basry, H. (1962) Kisah Gerila Kalimantan, Banjarmasin.

Blong, R. J. (1982) The Time of Darkness: Local legends and volcanic reality in Papua New Guinea, Canberra: ANU Press.

Bondan, M. (1992) Spanning A Revolution: The story of Mohamad Bondan and the Indonesian nationalist movement, Jakarta: Penerbit Sinar Harapan.

Coolhaas, W. Ph. (ed.) (1960) Generale Missiven van Gouverneurs-Generaal en Raden aan Heren XVII der Verenigde Oostindische Compagnie. Volume I, The Hague: Nijhoff.

Crawfurd, J. (1820) History of the Indian Archipelago, [3 vols], Edinburgh: Constable.

Crawfurd, J. (1971 [1856]) A Descriptive Dictionary of the Indian Islands and Adjacent Countries, Kuala Lumpur: Oxford University Press. 
Fox, J. J. (2005) 'In a single generation: a lament for the forests and seas of Indonesia', in P. Boomgaard, D. Henley and M. Osseweijer (eds), Muddied Waters: Historical and contemporary perspectives on management of forests and fisheries in island Southeast Asia, Leiden: KITLV Press, pp. 43-60.

George, M. (1980) Australia and the Indonesian Revolution, Melbourne: Melbourne University Press.

Knaap, G. J. (1987) Kruidnagelen en Christenen: De Verenigde Oost-Indische Compagnie en de Bevolking van Ambon 1656-1696, Dordrecht: Foris for KITLV.

Knaap, G. J. and H. Sutherland (2004) Monsoon Traders: Ships, skippers and commodities in eighteenth-century Makassar, Leiden: KITLV Press.

Dampier, W. (1981 [1729]) A Voyage to New Holland, (J. Spencer ed.), Gloucester: Alan Sutton.

Lockwood, R. (1975) Black Armada, Sydney South: Australasian Book Society.

Moorehead, R. J. (1934) The Cruise of the Goodwill Ship, Melbourne: Ruskin Press.

Moorehead, R. J. (1946) The Mists of Macassar, Melbourne: National Press Club.

Oppenheimer, S. (1999) Eden in the East, Phoenix, Ariz.: Orion.

Reid, A. (1986) 'Australia's hundred days in South Sulawesi', in Nineteenth and Twentieth Century Indonesia: Essays in honour of Professor J. D. Legge, Melbourne: Monash Centre for Southeast Asian Studies, pp. 201-24.

Reid, A. (1990) 'The Australian discovery of Indonesia, 1945', Journal of the Australian War Memorial, 17 (October), pp. 30-40.

Reid, A. (1995) 'Australia and Indonesia's Struggle for Independence', in A. Reid and M. O'Hare Australia and Indonesia's Struggle for Independence, Jakarta: Gramedia, 1995.

Wallace, A. R. (1869) The Malay Archipelago, London: Harper.

Warren, J. (1981) The Sulu Zone, 1768-1898: The dynamics of external trade, slavery, and ethnicity in the transformation of a Southeast Asian maritime state, Singapore: Singapore University Press.

Zaide, G. F. (1931) Documentary History of the Katipunan Discovery, Manila: Gregorio Zaide. 